schools. In the absence of prejudgment on the basis of a political creed which seems to regard income levels as the preponderant factor in classifying human beings, and automatically condemns as iniquitous those classes who start with a slightly higher income than others, the natural conclusion to be drawn from the success of men from these schools is that the schools are the best in the country, and is a good reason for continuing and even extending them. It is extremely foolish to begin reform of education by abolishing that type of school which, though not perfect, is at least as good as, and in some ways better than, any other.

It is unfortunately true that entry to public schools is almost entirely restricted to boys in the higher levels of family income, at present. This undemocratic feature has not been present throughout the entire history of these schools, and does not seem to be an essential feature of them. The admission of boys from elementary schools seems the right way to correct this fault. At present, there are considerable difficulties in the transition, partly because the boys destined for secondary education are drawn off from elementary schools some two years before the present normal age of entry to public schools, and the curricula of elementary schools do not lead naturally to those of public schools. These administrative difficulties should not be insuperable, with goodwill on both sides.

It is some decades since Oxford and Cambridge opened their doors widely to boys from all types of school, so that the society in universities is far more democratic than fifty years $\varepsilon$ go. This has not produced the "psychological dislocation" which the signatories to this letter anticipate; why should mixing of all classes of boys at school age produce this mental disease? It does not, in other countries where boys of all classes mix at school, and should not do so even in our ancient, or modern, public schools. The founders of our oldest public schools did not intend them to be reserved for the wealthy; and there is surely not so much difference in the nature of the boys from poorer and from richer families that they cannot mix ! I suspect that what the signatories to this letter really fear is not the effect on the minds of the boys, but the imperilling of the creed that the interests of the richer and poorer classes must for ever clash. I welcome the attempts to throw open our best public schools to boys of all degrees of wealth, both as fulfilling the original intentions of the founders of these schools, and as an important step to the abolition of class distinctions.

University College,

N. K. ADAm.

Southampton.

Sept. 22

\section{Private Schools in America}

THE letter on "The Public Schools in Great Britain" (Nature, Sept. 19, p. 351), in its references to the system in America, does not show much acquaintance with the American scene.

There are in America half a million pupils in private schools - schools maintained solely by fees and endowments. Even allowing for a population in America three times that of Britain, one may say that this figure of half a million represents proportionately a private-school enrolment in America at Jeast twice as large as the public-school enrolment in Britain.
In neither country;, I submit, is the factor of wealth so excluding, so all-pervading, as the signatories of that letter suggest it is in Britain. As in Great Britain numerous scholarships are open to pupils of small means, so they are in America.

An important aim of American private schools is to set a standard of manners-a thing difficult to preserve in an American pupil if he lives in a metropolitan area and has for years to attend a taxsupported school largely populated by children of immigrants. However, American private schools are not divorced from democracy. For example, many of them serve the community in which they are located by offering night courses for adults, or serve the nearest metropolitan district by operating summer camps for city children. In both these activities the senior private-school pupils themselves take part. Willard ConNely.

American University Union,

1 Gordon Square, W.C.J.

\section{Science and Organization}

I READ with much interest the leading article in NATURE of September 12 on the "Organization of Science for War". There are few scientific workers who will not agree with the need for careful planning, both for the conduce of the War and for the urgent problems which must be solved in the post-war years : so far from wishing to criticize this point of view, many have complained, as is noted, of the inadequacy of organization and of the failure to utilize their skill.

But while these views are almost universally held, I believe that many man of science will regret som the references to those scientific workers who are convinced that there are other considerations of importance. It is unfortunate to suggest that scientists "have spent too much time squabbling among themselves over such questions as to what extent science should be planned", for surely such discussions have in fact occupied few scientists for very little time; in any event, "in the democracy for which we are fighting" we may anticipate that it will not be thought improper for scientific workers who recognize their duties to society to put forward views regarding the extent to which scientific research can advantageously be planned.

While convinced of the nesd for the planning or co-ordination of research both for the present and for the immediate future, I would suggest that any long-term plan must recognize that, in addition to a main body of directed investigators, there must be the largest possible number of 'free' researchers, acting as pioneers in the opening of new spheres of work. For many reasons, it would be desirable that much of this pioneer activity should be centred, as at present, in the universities.

In this connexion, too, it is to be hoped that those concerned with planning will not overlook the cultural aspects of science: unless art, music and poetry are to be frowned upon, there must surely be a place for scientific work for which no probable utilitarian value can be foreseen.

To many these views will probably be no more than platitudes, but they are restated briefly in the hope that some confused issues may be clarified.

University of Glasgow. A. E. Trueman. Sept. 24. 